\begin{tabular}{|l|c|c|c|r|}
\hline $\begin{array}{l}\text { Cuadernos de Investigación Geográfica } \\
\text { Geographical Research Letters }\end{array}$ & 2018 & $\mathbf{N}^{\circ} 44(2)$ & pp. 535-555 & $\begin{array}{r}\text { ISSN 0211-6820 } \\
\text { eISSN 1697-9540 }\end{array}$ \\
\hline
\end{tabular}

\title{
EVOLUTION OF SCIENTIFIC QUESTIONS OVER 50 YEARS IN THE KERVIDY-NAIZIN CATCHMENT: FROM CATCHMENT HYDROLOGY TO INTEGRATED STUDIES OF BIOGEOCHEMICAL CYCLES AND AGROECOSYSTEMS IN A RURAL LANDSCAPE
}

\author{
C. GASCUEL-ODOUX ${ }^{1 *}$, O. FOVET ${ }^{1}$, G. GRUAU ${ }^{2}$, L. RUIZ ${ }^{1}$, P. MEROT $^{1}$ \\ ${ }^{1}$ UMR SAS, INRA, Agrocampus Ouest, 35000 Rennes, France. \\ ${ }^{2}$ Géosciences Rennes, Université Rennes 1, CNRS, 35000 Rennes, France.
}

\begin{abstract}
Catchment studies on water quality started in the 1960s, when scientists identified long-term environmental impacts and realized the complexity involved in environmental degradation and recovery. Since scientists need to understand biogeochemical and hydrological processes in detail, long-term observatories have been established over time, particularly in the field of catchment hydrology and biochemistry. The AgrHyS (for "AgroHydroSystem") observatory comprises two small catchments in Brittany (France) and this article unfolds the evolution over 50 years of the scientific questions and related observations and studies in one of them, the Kervidy-Naizin catchment. While a well-defined set of variables was monitored since the beginning (the "basic observatory basket"), the research topics and additional monitored variables were much broader. The first 25 years focused on hydrological and biogeochemical processes, while the next 25 years focused on more integrated issues related to soil ecology and landscape biogeochemical cycles. The AgrHyS observatory has succeeded in fostering interdisciplinary research. The current challenge is the engagement of the observatory in international networks to enable inter-comparison of hydrosystems response to gradients of different land use and environmental conditions.
\end{abstract}

Evolución de las preguntas científicas planteadas en la cuenca de KervidyNaizin a lo largo de 50 años: de la hidrología de cuenca a estudios integrados sobre ciclos bioquímicos y agrosistemas en un paisaje rural

RESUMEN. Los estudios sobre calidad de agua en cuencas empezaron en los años 60, cuando los científicos identificaron el alcance de los impactos medioambientales a largo plazo y reconocieron la complejidad de la degradación y recuperación medioambiental. Dado que los científicos necesitan entender los procesos bioquímicos e hidrológicos en detalle, a lo largo del tiempo se han ido estableciendo observatorios a largo plazo, especialmente en relación con la hidrología y la bioquímica en cuencas. El observatorio AgrHyS (de "AgroHydroSystem") 
incluye dos pequeñas cuencas en Bretaña (Francia) y este artículo explica la evolución de las preguntas científicas planteadas y las observaciones y estudios asociados a lo largo de 50 años en una de ellas, la cuenca de Kervidy-Naizin. Si bien un conjunto de variables bien definidas se han monitorizado desde el principio (constituyendo la "cesta básica del observatorio"), los temas de investigación y el seguimiento de variables adicionales ha sido mucho más amplio. Los primeros 25 años se centraron en procesos hidrológicos y bioquímicos y los 25 años siguientes se centraron en cuestiones más integrales relacionadas con la ecología del suelo y los ciclos bioquímicos del paisaje. En este sentido, el observatorio AgroHyS ha sabido fomentar con éxito una investigación multidisciplinar. El reto actual es la integración de este observatorio en redes internacionales que permitan la inter-comparación de la respuesta de los sistemas hydrológicos en gradientes de condiciones ambientales y de usos del suelo diferentes.

Key words: research catchment, long-term monitoring, interdisciplinary research, environmental observatory.

Palabras clave: cuenca de investigación, monitoreo a largo plazo, investigación interdisciplinar, observatorio medioambiental.

*Corresponding author: Chantal Gascuel-Odoux, UMR SAS, INRA, Agrocampus Ouest, 35000 Rennes, France. E-mail address: chantal.gascuel@inra.fr

\section{Introduction}

Awareness of water quality degradation in the 1960s stimulated establishment of highly equipped catchments to understand the relationships between changes in human activities and those in water resources (quantity and quality). Initially, these catchments were selected and their monitoring designed to address a specific issue such as acid rain, chemistry production, agriculture, landscape management or deforestation. In agricultural catchments, the objectives were to quantify the increasing load and concentration of nutrients and pesticides in stream water and to understand the hydro-biogeochemical processes influencing these increases. The setting up of well-equipped catchments was the scientific response to the societal demand for understanding and solving specific environmental problems.

By doing so, the scientific community discovered that water and biogeochemical cycles have been deeply disturbed for a long time. New concepts were introduced in scientific debates, such as "variable source areas" and "buffer zones". The accumulation of data stimulated the development of computer models. Monitored catchments, established as a tool for addressing societal questions, were increasingly considered as complex environmental objects, which stimulated new scientific questions that have evolved over time. As Ambroise (1999) noted, scientists moved "from BVER (Bassin Versant Expérimental Représentatif) to BVR (Bassin Versant de Recherche)", i.e. "from Representative Experimental Catchment to Research 
Catchment", that is to say, from a period when scientists observed or performed experiments for examining changes in catchments and their effects, to a period when scientists raised new scientific questions by observing catchments. Environmental observatories have been created worldwide, encouraged by the International Association of Hydrological Sciences (IAHS) in 1965. International networks of well-monitored sites were established much later including the Long-Term Ecological Research (LTER) network of the ecological community (Callahan, 1984), the Long-Term Agroecosystem Research (LTAR) network of agricultural catchments (Walbridge, 2013) and the Critical Zone Observatory (CZO) network in the United States (Anderson et al., 2008). Scientists involved within the Kervidy-Naizin catchment have been fully engaged in these national and international scientific projects. The objectives of this article are 1) to describe the co-evolution of scientific questions, equipment and scientific structures in Kervidy-Naizin, viewed as a research catchment and as a site belonging to a network; 2) to describe current scientific and data production from this catchment as well as the future perspectives; and 3) more generally, to highlight the utility of a long-term catchment observatory such as Kervidy-Naizin for environmental research, as a research object and as a reference for society. The aim of this article is definitely not to summarize the knowledge acquired from the catchment, already described in many publications, but to analyze the coevolution of science, catchment instrumentation and societal issues for approximately 50 years, from the 1970 s to 2015 s.

Studies in the Kervidy-Naizin catchment started in 1970; in 1990, a second catchment (Kerbernez), focused on recharge processes and water residence time, was incorporated. The two catchments, which research was complementary, formed the AgrHys (for "AgroHydroSystem”) observatory. In June 2017, 30 articles that mentioned the Kervidy-Naizin catchment in the title or abstract were found in the Web of Science ${ }^{\circ}$; they had an H-index of 14 and 750 citations, which could be considered relatively low. Indeed, about 110 scientific articles from this catchment have been published to date but "Kervidy-Naizin catchment" was not always named in their titles or abstracts, since many of these research papers favored genericity over local contexts. It is also noteworthy that the publication of the results in international journals started only in the 1990 s, i.e. 20 years after the initiation of the monitoring. This is partly due to the fact that initial studies were focused on societal issues and the production was essentially in the form of reports to stakeholders, and partly because many scientific questions can be identified and addressed only when sufficiently long time series have been accumulated.

\section{The Kervidy-Naizin catchment}

The Kervidy-Naizin headwater catchment $\left(5 \mathrm{~km}^{2} ; 2\right.$ nd Strahler order $)$ is located in the middle of Brittany (Fig. 1), an intensive agricultural region in western France. It has gentle slopes $(<5 \%)$ and loam and sandy loam soils 0.3-1.0 m deep, distributed in three domains: poorly drained soils in bottomlands, moderately well-drained soils in mid-slope areas and well-drained soils in upland areas. The catchment's stream network is $4.4 \mathrm{~km}$ long and its bedrock is dominated by schist underlain by a weathered zone 1-30 m deep. A shallow aquifer consisting of a highly and seasonally fluctuating water table, developed in the soil of the bottomlands and in the weathered layer of the hillslopes, feeds the stream. The intermittent 
stream dries out in summer, when it is no longer fed by groundwater. The climate is temperate and humid. For the period $1995-2015$, mean annual temperature was $11.6^{\circ} \mathrm{C}$ and rainfall was $846 \pm 207 \mathrm{~mm}$. Mean annual runoff was $349 \pm 167 \mathrm{~mm}$ and mean annual Penman potential evapotranspiration was $698 \pm 52 \mathrm{~mm}$.

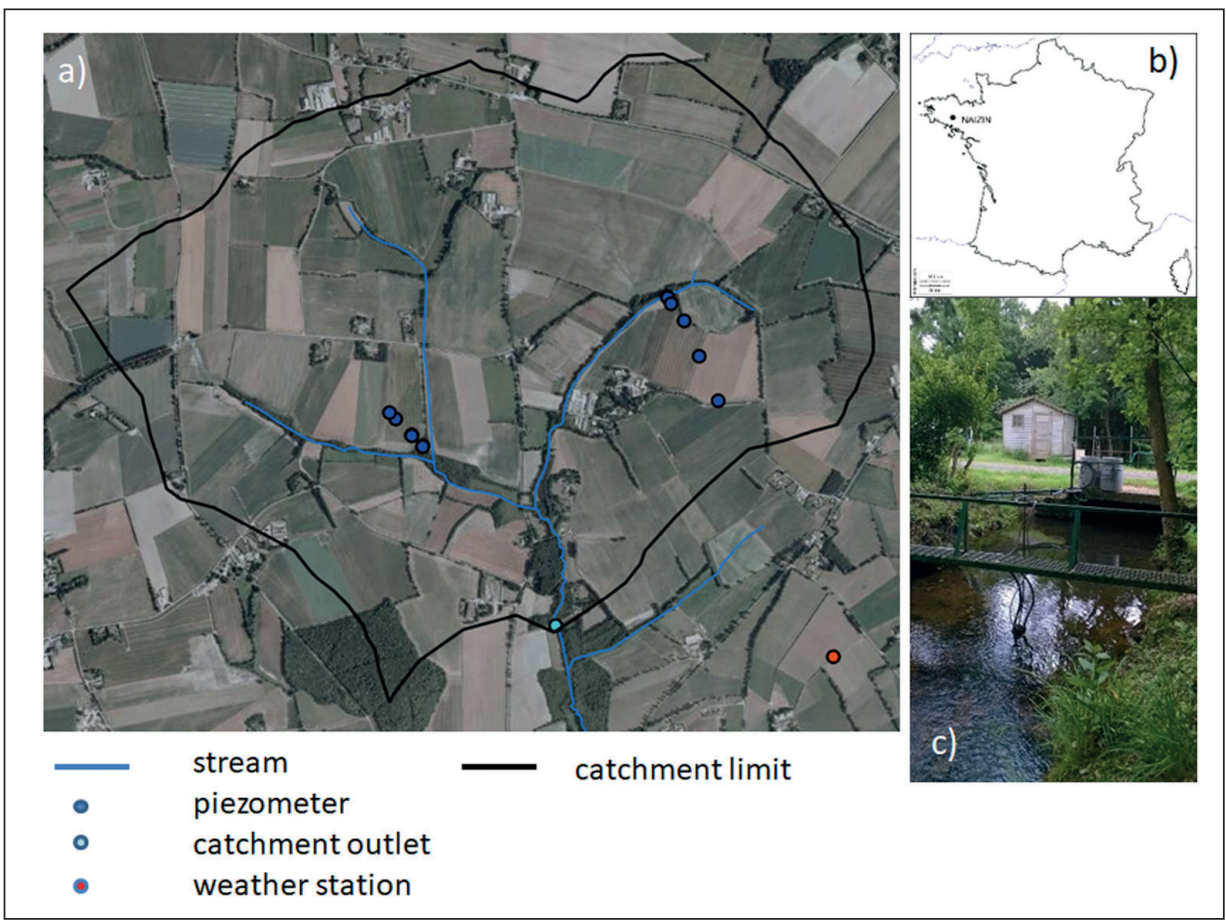

Figure 1.a) Aerial view of the Kervidy-Naizin catchment and location of the main instruments, b) location of the Kervidy-Naizin catchment in France and c) some of the equipment installed at the catchment outlet.

The current landscape is dominated by crop-livestock farms, including intensive pig and dairy farming. The Usable Agricultural Area (UAA) is covered by cereals and rapeseed (ca. 30\%), grassland (ca. 30\%) and maize (ca. 30\%). The land use is a result of the large livestock production $\left(35,000\right.$ pigs $\mathrm{yr}^{-1}, 40,500$ poultry $\mathrm{yr}^{-1}, 3000$ cattle $\left.\mathrm{yr}^{-1}\right)$. The nitrogen balance from the 23 farms located in the catchment was estimated in $200 \mathrm{~kg} \mathrm{~N} \mathrm{ha}^{-1}$, and 33 crop successions were identified, representing 47 cropping systems mainly distinguished by fertilization (amount, organic and mineral ratio) (Akkal, 2010). The landscape and the agricultural activities have co-evolved significantly. Intensive regrouping of agricultural land between 1971 and 1976 increased mean field area by a factor of three and destroyed approximately $80 \mathrm{~km}$ of hedgerows and associated banks. The catchment still has residual hedgerows along streams at a lower density (ca. $40 \mathrm{~m} \mathrm{ha}^{-1}$ ) compared to the initial values (ca. $70 \mathrm{~m} \mathrm{ha}^{-1}$ ). Permanent grasslands are now located only in riparian wetlands. Intensive animal production increased by a factor of six between 1975 and 1995 while grassland area decreased by half and was mainly replaced by arable crops, particularly maize. The nitrate concentration at the stream outlet increased from less than 10 to more than 
$70 \mathrm{mg} \mathrm{l}^{-1}$. From 1995 to now, the greatest modifications of the landscape were due to administrative regulations, as for example the limitation of nitrogen input to $170 \mathrm{~kg} \mathrm{~N} \mathrm{ha}^{-1}$ or the implementation of the $5 \mathrm{~m}$ width vegetated buffer strip along the stream.

\section{Environmental issues, research approaches and main findings}

Environmental issues have clearly determined the catchment set up and its evolution, so that a large variety of topics and approaches have been developed in Kervidy-Naizin during the last 50 years. This co-evolution between environmental issues, research topics and approaches is summarized in Figure 2. Ten steps can be distinguished: 1) water as a social issue, and water and nutrient budget as first steps; 2) riparian wetlands as buffering systems for water and nitrogen transfer; 3) the intrinsic structure of the catchment in space and time, i.e. how topography and groundwater interact with soil and crop distribution; 4) catchment response time: combining modelling and tracers; 5) inter- and intra-annual variations of stream water chemistry as the result of the dynamics of soil-groundwater interactions; 6) simulating scenarios for helping transitions in agroecosystems and landscape for higher nutrient efficiency and lower nitrate export; 7) soil, water and atmospheric interactions, including emissions and depositions, in relation with agroecosystems; 8) extension to phosphorus and organic matter; 9) revisiting chemistry of storm events, their variations along the hydrological year and in the longterm; and 10) soil and water ecology, interactions between biotic and abiotic components.

These ten steps can be divided into two periods: a deterministic one focusing on nitrogen cycling, and a more integrative one in which all the key nutrients and compartments were considered.

- During the first period (1970-1995), the main objective was to understand the functional and dynamic structure of the catchment in space and time, which enabled the explanation of water and nitrogen exports from storm to decade scales by studying spatial and temporal aspects of cropping systems, soils, wetlands and groundwater. This was clearly a deterministic approach starting with the catchment as an essential unit of study, and breaking it down into different landscape elements associated with biogeochemical processes such as production, storage and biotransformation.

- During the second period (1995-2015), the main objective was to expand the approach used for nitrogen cycling to the cycling of many other chemical elements present in rural landscapes, including the atmospheric, solute and particulate phases in water. The temporality in water quality was particularly well investigated, at the short term by studying storm events, and at the long-term by studying response time, inter-annual variations and trends.

While the first period mobilized a small group of approximately 20 scientists with specialties in hydrology, soil science and biogeochemistry, the second period mobilized two or three times as many scientists including international collaborations, from a broader array of environmental sciences, including biologists and particularly microbiologists. These ten steps are described in detail below. The equipment and the data acquisition that correspond to these ten steps are summarized in Figure 3. 


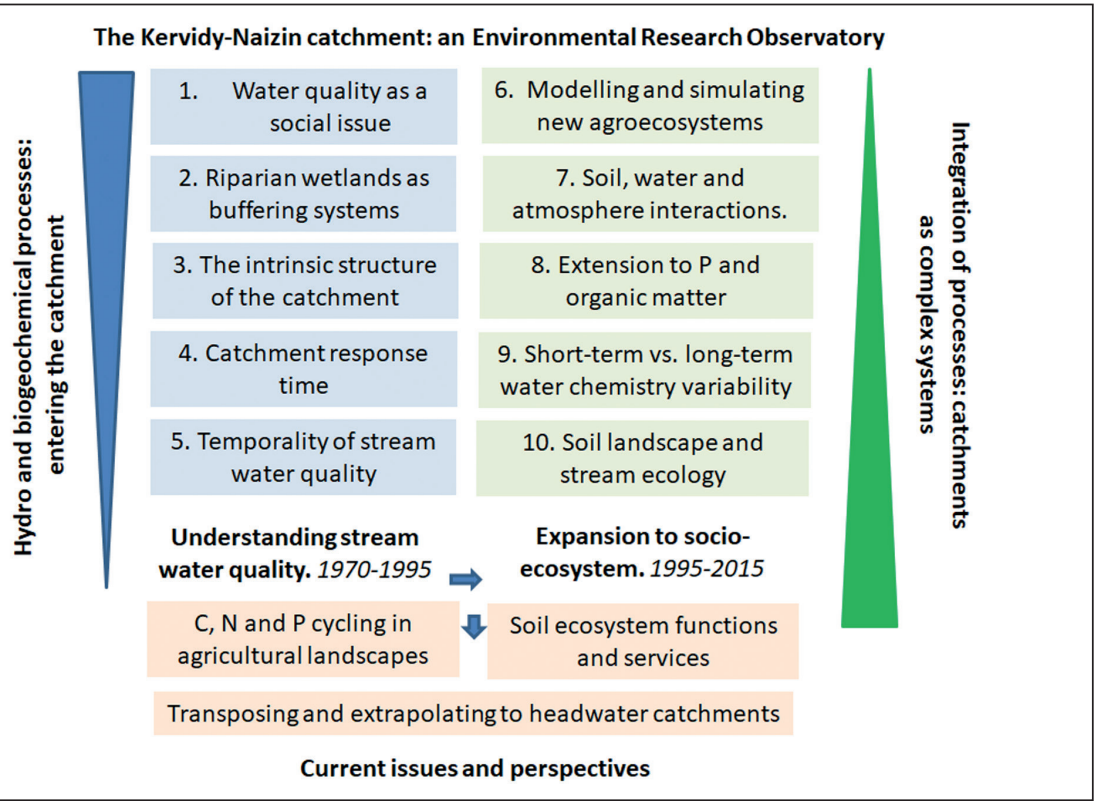

Figure 2. Historical retrospective and perspective of the main topics addressed in the KervidyNaizin catchment.

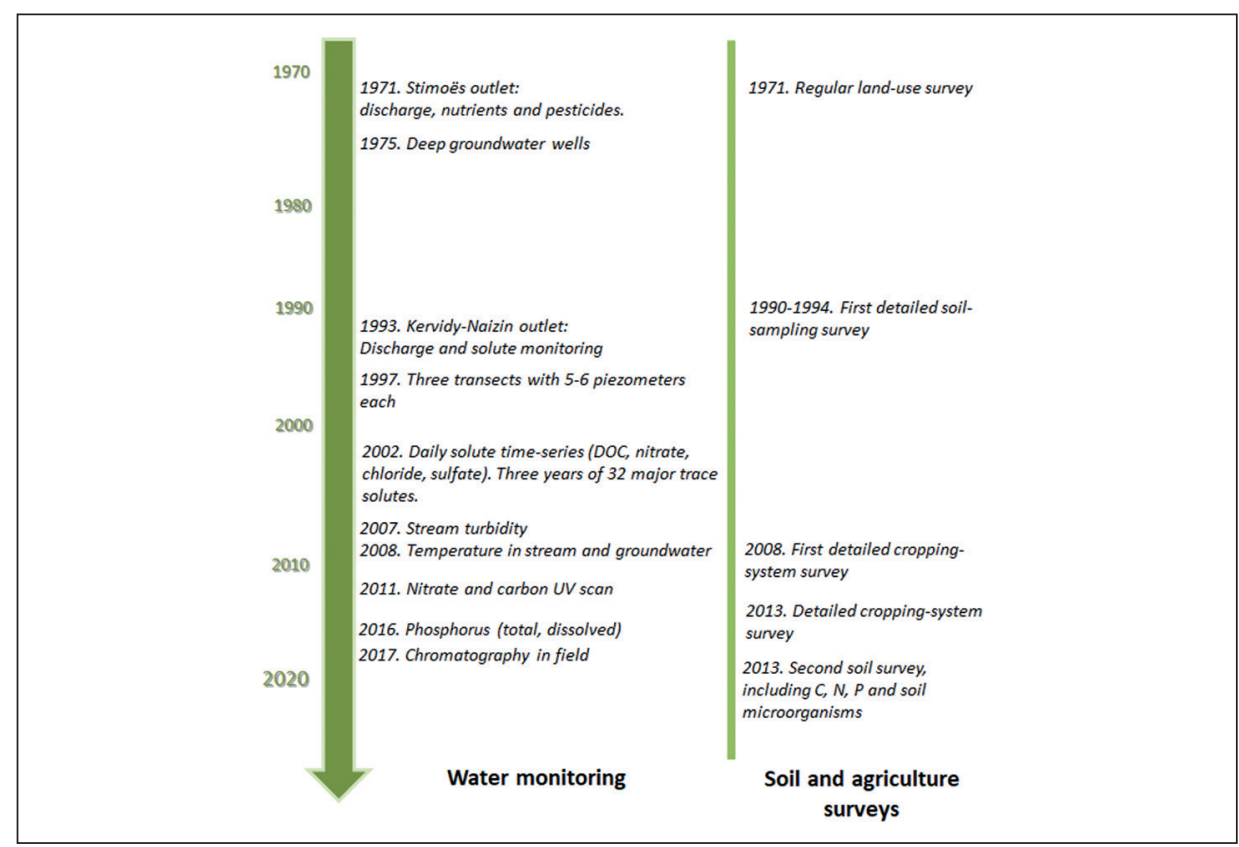

Figure 3. Historical retrospective of the equipment installed and the soil and agricultural surveys undertaken in the Kervidy-Naizin catchment. 


\subsection{Step 1. Water quality as a social issue}

\section{Environmental issue: nutrient balances to locate the problem}

Scientific studies in the Kervidy-Naizin catchment started in 1971, with the analysis of nutrient balances from fields (annual agricultural balances) and at the catchment outlet (annual loads), and the deduction of nutrient transfer into the soil up to the stream, along with variations in concentrations of nutrients, pesticides and bacteria in stream water (Cann, 1998a,b). These studies aimed at calculating nutrient balances in order to identify the effects of land regrouping and agricultural intensification on stream water quality. They examined broad issues considering the system as static (i.e., 1998b without studying its dynamics), using statistical approaches, formulating mechanistic hypotheses about input-output relationships and setting up the observations needed to analyze these relationships. Although these approaches were exploratory and empirical, they represented a starting point.

\section{Approach: equipment at the outlet, agricultural surveys and nutrient monitoring}

The first studies were performed at the scale of the Naizin catchment (ca. $12 \mathrm{~km}^{2}$ ), to which the Kervidy-Naizin sub-catchment belongs. The Naizin catchment outlet, called "Stimoës", was equipped in 1971 to measure streamflow. Rainfall and water table depth were respectively monitored with a meteorological station and three piezometers, located near the catchment outlet, for investigating the water quality of the groundwater at different depths. The land use was surveyed each year and the agricultural practices of farmers, particularly fertilization, were (poorly) determined using administrative databases and a single detailed survey. In 1975, additional chemical elements (nitrate, ammonium, total phosphorus and phosphate, and certain pesticides) were monitored at Stimoës for few flood events and regularly between flood events. Gradually, sampling frequency increased in time but also along the stream. Unfortunately much of these data have been lost, probably because of the lack of computer tools to store them properly (at that time paper was the only way to store data), and the insufficient awareness about the fact that the control of nutrient emissions was a long-term and a collective scientific topic.

\section{Key findings: high nutrient balance and "hot moments"}

This first monitoring step has emphasized the leaks of nitrogen and phosphorus from agriculture, the "hot moments" of phosphorus and pesticides exports, as well as the lack of apparent effect of hedgerows removal on the water budget.

\subsection{Step 2. Recognizing riparian wetlands as buffering systems for water and nitrogen transfer}

Environmental issue: wetlands management based on the recognition of their multifunctionality, particularly hydroecological functions such as denitrification

In the 1990s, hydrologists started to promote the concept of source areas. Riparian wetlands, where the water table interacts with shallow soil horizons, vary in space and time as a function of climate, topography and geomorphology 
(Crave and Gascuel-Odoux, 1997). They are key elements of the landscape that control hydrological and hydrochemical dynamics at the catchment scale (Beven and Kirkby, 1979; Bullock and Acreman, 2003). Wetland extent was considered a proxy of the wetness conditions of the catchment, which can be used to limit predictions of discharge by hydrological models. Also, their redox conditions can control biogeochemical transformation processes such as denitrification. From an environmental protection perspective, these highly "reactive" areas could be managed to optimize their buffering functions, but they have firstly to be recognized as places to be protected (Merot et al., 2006).

Approach: Remote sensing and modeling of riparian wetlands and their hydrological and biogeochemical functions

Wetlands were first inventoried on foot and then by helicopter-borne radar to estimate their spatial and temporal variations as well as their denitrification potential (Merot et al., 1994). The first modeling study, using TOPMODEL, was carried out to calibrate the model using the dynamics of the riparian wetlands (Franks et al., 1998). It was later supplemented by end-member analysis and modeling of floods to estimate wetland contribution to flood events (Durand and Torres, 1996). These pioneering wetland studies formed the basis of research up to present, which has progressively extended the focus to solutes (first nitrogen, then carbon, iron, and trace metals including rare earth elements, in field and laboratory experiments) (Dia et al., 2000) and other water compartments besides soil water (groundwater and stream water).

Key findings: wetlands as hotspots for studying catchment hydrological and biogeochemical dynamics

The major hydrological and biogeochemical role of wetlands in crystalline catchment response to storm events was shown. This role was mainly controlled by i) the variations in space and time of the interactions between soil and subsurface flow, which determine redox conditions, ii) the connectivity of wetlands with the hillslopes, iii) the water residence time in the wetlands, and iv) the nitrate input and the richness in organic matter as fuel for denitrification. All this contributed to determine the potential denitrification function of wetlands.

\subsection{Step 3. Entering the catchment: studying its intrinsic structure}

\section{Environmental issue: catchment as a system to be managed}

The 1990s were also characterized by the analysis of the spatial distribution of soil constituents and soil physical properties as major factors for explaining water and nutrient export. Regarding physical properties, two domains in the catchment were distinguished: well-drained soils on the hillslopes, with vertical transfer, contrasting with waterlogged and low conductivity soils in bottomlands, with lateral surface and subsurface transfers (Curmi et al., 1998). This study was among the first attempts to digitally map soil properties, mainly soil hydromorphy and soil carbon content (Merot $e t$ al., 1995; Chaplot et al., 2000, 2001). 


\section{Approach: inventorying and building agricultural and soil databases}

Soil surveying, description and analysis required intensive work by the soil science group. Approximately 30 soil profiles were described and 200 soil samples were analyzed between 1990 and 1994. The soil analysis included aggregate stability by soil tests in laboratory, and surface runoff monitoring by capturing, in the field, the surface runoff for individual storm events on two transects (Le Bissonnais et al., 2002). Data from water and soil analysis started to be recorded in 1990. However, only some of these earlier soil data remain available, as many others have been definitely lost, such as the concentration of solutes along the watercourse. Description of agricultural practices, however, remained limited at that time and was based on a single survey of land use. These years were marked by the publication of two books (Cheverry, 1998; Merceron, 1999) that summarized the knowledge gained, respectively, about the relationship between intensive agriculture and water quality, and nonpoint source pollution. These books were disseminated among water and agricultural managers.

\section{Key findings: topography as a major factor for soil spatial distribution}

A catchment is structured according to the spatial distribution of the soil properties, which is partly determined by the topography and the position of the water table within this topography. The effect of agricultural activities on soil and water depends on their position in the catchment, particularly their slope position.

\subsection{Step 4. Catchment response time: modeling and predicting nitrate export}

\section{Environmental issue: estimating water and nitrate transfer times}

In the early 2000s, studies focused on the effects of water table fluctuation on nitrate transfer, the role of riparian wetlands in denitrification, and water and nitrate transfer time estimations along the soil-groundwater-stream continuum. It was hypothesized that the weathered layer stored nitrate, explaining the catchment's slow response to changes in agricultural practices. The seasonality of nitrate concentrations was related to variations in water table depth and hydraulic gradient, inducing variations in connectivity among catchment water compartments (wetland water, upland shallow groundwater, deep groundwater).

Approach: massive hydrological and groundwater equipment, tracers and agro-hydrological modeling

A large variety of field equipment was installed to monitor and study water and solute fluxes. In 1993, a new gauging station was installed at the outlet of the Kervidy-Naizin catchment to replace the old Stimoës station (closed a few years later despite its official disappearance in 1988 in the national database) and to avoid chemical inputs from the village of Naizin, where a water treatment plant and recreational area were built, thereby restricting future studies on strictly diffuse agricultural pollution. A new meteorological station was installed at a location called "Le Toullo". Finally, three transects called "Fournello", "Kerroland" and "Gueriniec" were equipped in 1997, each with 5-6 piezometers 1-6 m deep, to monitor water table depth and groundwater chemistry. The water and nitrate transit time 
over the catchment was modeled using the MODFLOW model, which was calibrated using streamflow and water table depth observations, and innovative modeling methods such as spectral analysis were applied (Molenat et al., 1999, 2005, 2008; Molenat and GascuelOdoux, 2002). Most of these studies targeted nitrate. Data acquisition on the agricultural systems such as crop rotation and fertilization remained occasional during these years, resulting in a weakness point of the observatory. Chlorofluorocarbures and hexafluorures were used as tracers to date groundwater (Molenat et al., 2013). Additional groundwater monitoring equipment (ca. 60 wells) was installed in the Kerbernez catchments, a set of very small catchments on granite, in which nitrate concentrations presented different temporal signatures, and for which groundwater modeling and inter-comparison between catchments were developed (Molenat et al., 2013; Fovet et al., 2015).

\section{Key findings: transfer time depends on length, shape and slope position}

The shallow groundwater was established as a key component of the catchment system because of its key role as a storage compartment of nitrogen. This fact explained the relatively long water and nitrate residence times despite the limited reservoir.

\subsection{Step 5: Trends, inter-annual and seasonal dynamics of stream water chemistry}

Environmental issue: explaining the spatial and temporal variability of stream water chemistry

In the 2000s, we started to understand that the chemical signature of stream water resulted from water coming from different compartments of the catchment over time, along with biogeotransformations and mixing during their transfer, and that having a multi-element approach was essential to identify all active reservoirs. Wetland soils were considered as references to test biogeochemical reactivity of rare earth elements, arsenic and iron, according to redox variations (Davranche et al., 2005; Grybos et al., 2007; Pourret et al., 2007).

Approach: high-frequency and high-resolution water analysis, lab experiments in biogeochemical reactors

In 1999, nitrate, chloride, sulfate and dissolved organic and inorganic carbon started to be daily monitored at the outlet of the catchment by a municipal employee who has regularly collected water at daily frequency since then. The collected chemical elements constituted the basic basket of the water chemistry monitoring. During the first three years (1999-2002), 32 major and trace-element cations including calcium, sodium, magnesium, iron, rare earth elements, zinc and copper were added to this basic list. In 2002, the first database, called the "AgrHys database", was created and has been maintained and updated up to now. This long-term and high frequency database is probably the only one of its kind in the world. Making the catchment's data available to the scientific community has been always a major goal of the observatory. Analysis and publication of this time-series has been, however, quite recent (Aubert et al., 2013, 2014). Additionally, lab experiments were developed in biogeochemical reactors, considered as mesocosms, to study the effect of temperature and redox conditions on water quality. 
Key findings: complex water chemistry of stream water as a result of the mobilization in time of different catchment compartments

A decade of field monitoring enabled the investigation of catchment response to the variability of climatic conditions and of the mobilization of elements stored in different catchment compartments due to bedrock weathering and agricultural activities. These studies showed that groundwater fluctuations and its interactions with soil were the main drivers for sources-stream connectivity and sources dynamics, which can impact wetness and redox variations and thus dissolved organic carbon, metals and rare earth elements in wetlands.

\subsection{Step 6. Modelling and numeric experiments for adapting agroecosystems to lower nitrate export}

Environmental issue: changing agroecosystems to meet the Water Framework Directive (WFD) targets

Since 2000, the knowledge accumulated on the influence of groundwater, riparian wetlands and stream water on nitrogen cycling in landscapes has enabled the development and calibration of agro-hydrological models that have been used to test the effects of management scenarios on nitrate emissions in stream water. This topic has been stimulated by regional environmental concerns such as coastal eutrophication, which was and remains a hot topic in Brittany and for which nitrate is the main driver.

\section{Approach: modeling scenarios for landscape nitrogen management}

Around 2000, the semi-distributed TNT2 model (Beaujouan et al., 2002) was developed, coupling: i) STICS, a crop model, ii) TOPMODEL, a hydrological model, and iii) the denitrifying functions of wetlands. The TNT2 model was used to test remediation hypotheses for improving nitrate concentration in stream water. More than 10 years were necessary to go from model design to model application for operational purposes. The Kervidy-Naizin catchment was considered a reference catchment for calibrating models and testing the effects of agricultural (intercrops, conversion to grasslands, etc.) or landscape management scenarios (hedgerow density, protection of riparian wetlands, etc.) (Viaud et al., 2005; Benhamou et al., 2013) on stream nitrate export (Durand et al., 2015).

Key findings: multiple agricultural and landscape changes have to be implemented to reach on the long-term the river nitrate concentrations targeted in the WFD

Developing and calibrating models in Kervidy-Naizin was possible thanks to the high quality input data. Applications of the TNT2 model enabled testing hypothesis and demonstrated the real but limited effect of the landscape actual epuration (due to the wetlands or the bocage preservation) compared to the effect of agricultural practices. Despite of the regulation, some of the current cropping systems can still present higher nitrate leaching that those targeted in the WFD. 


\subsection{Step 7: Agroecosystem soil, water and atmospheric interactions}

Environmental issue: atmosphere phase, nitrogen emission and deposition, carbon sequestration

The wealth of the catchment's data, as well as the uniqueness of the catchment in terms of its high positive nutrient balance, high carbon storage in the wetlands and high ammonia concentrations in the atmosphere from livestock production, had attracted a large variety of scientists, particularly soil and atmospheric scientists working on carbon and nitrogen exchanges at the soil-atmosphere interface.

\section{Approach: soil and atmospheric observations}

Equipment and surveys have been setup and conducted to analyze nitrogen gas emissions and depositions (ammonia and nitrogen oxides), soil carbon mineralization and soil $\mathrm{CO}_{2}$ emissions, especially in wetlands, due to their fluctuating water tables and redox conditions (Tete et al., 2015; Bell et al., 2017; Buysse et al., 2016).

\section{Key findings: unusual amount of nitrogen emission and deposition}

Atmospheric ammoniac emissions were considerable due to livestock farms. These were a major hot spot of emission and short distance deposition. The temporal and spatial variability of in situ nitrogen oxides emissions was high due to the heterogeneity of the landscape.

\subsection{Steps 8: Extension to phosphorus and organic matter}

\section{Environmental issue: toward global nutrient cycling in catchments}

Based on the knowledge acquired about nitrogen dynamics and due to the societal demand to consider multiple nutrients in catchment mitigation strategies, around 2010 two research groups of scientists, working in two different projects, initiated studies on carbon and later on phosphorus. They shared the equipment for collecting soil water and soil data. Dissolved organic carbon and phosphorus emissions in stream water were linked to fluctuations in groundwater during flood events. Both nutrient production and export were controlled by the same key processes over time, mainly during autumn flushes, when catchment is re-wetting and water table joins the soil organic horizons in bottom lands, anoxic conditions at the end of winter, and soil mineralization in spring.

Approach: monitoring phosphorus speciation in soil water in wetlands and instream water

Two riparian wetlands were equipped with water traps (microlysimeters) to collect soil water, and samples were taken over several seasons (Morel et al., 2009; Lambert et al., 2011). In 2013, i.e. 12 years after the first soil survey was carried out, the soils of the Naizin catchment were surveyed again and analyzed in detail for their carbon, nitrogen and phosphorus contents, considering total and extractible phase. For this purpose, around 200 soil samples were collected. Batch experiments were performed to analyze the effects of environmental drivers such as water content, 
temperature and redox potential on carbon and phosphorus release (Dupas et al., 2015a, 2015b; Humbert et al., 2015; Gu et al., 2017). New surveys were performed to examine antibiotics in manure, soil and water, considered as specific organic molecules. Batch incubation experiments on soils from riparian wetlands have clarified the roles of organic matter in complexing and transporting trace metals in soil and stream water (Davranche et al., 2011).

In 2010, a new database was created using the Hydras software (https//www.ott. com/products/software-solutions-6/ott-hydras-3-386/), a friendly interface for data visualization and management. This software allows the data to be transferred directly from the field to the laboratory via mobile phone services and to be visualized, and thus validated, as they are collected. This involves all the data that are monitored by sensors, such as stream water depth, water table depth, temperature and electrical conductivity. Geo-referenced tools have been developed to locate the sampling points in the catchment in a new data portal called GeoSAS (https//geowww.agrocampus-ouest.fr/portails/ portail.php?portail=vidae). In GeoSAS, AgrHys database is always used as a backup tool and data can be displayed point by point.

\section{Key findings: processes involved in carbon and phosphorus export}

Results showed the unexpected importance of dissolved form of phosphorus, and tight similarities between dissolved phosphorus and carbon behavior, involving similar mechanisms for their mobilization, were underlined. Methods to monitor veterinary products and to estimate phosphorus fluxes were developed with reasonable uncertainty.

\subsection{Step 9. Short- (storm events) vs. long-term (decades) water chemistry variability}

Environmental issue: particulate and solute export regimes due to climatic conditions and agricultural activities

Because carbon and phosphorus are mainly exported during storms, studying both dissolved and particulate fractions and increasing the sampling resolution to the stormevent time scale were considered important goals. Dissolved fractions were dominant during storm events, contradicting the presumably stronger influence of particulate phases. The timing of the storm events throughout the hydrological year (i.e. their position within the hydrological year) was identified as a factor strongly influencing the variations in the "chemograph" of the storm events. Temporal patterns of water chemistry variations over long and short terms are now available for the Kervidy-Naizin catchment, allowing the study of the temporal relations between chemical parameters.

\section{Approach: automatic monitoring in the catchment}

High-frequency (10 minutes) sensors recording physical parameters and chemistry of water have been installed at the outlet of the catchment over time, including flow depth (1993), electrical conductivity and water table depth (1997), temperature and turbidity (2007), dissolved organic carbon and nitrate by UV-visible absorbance (2011) and phosphorus by Phosphax (2016). The current step is the installation of a chromatograph, 
i.e. an in situ ICP-MS (Inductively Coupled Plasma Mass Spectrometry) that can analyze all the anions and cations on a water sample taken from the stream every 20 minutes.

Key findings: renewal of the understanding of the storm processes

The past daily data and the recent high frequency data on nitrate and dissolved organic carbon collected by field monitoring showed that the seasonal variability during storms is partly controlled by groundwater fluctuations that determine the connection of runoff and the stream (Fovet et al., 2018). All these recent monitoring, particularly of all the anions and cations, are currently in development.

\subsection{Step 10. Ecological integration: interactions between biotic and abiotic components}

Environmental issue: biotic control of nutrient cycles

Biota drives processes that control carbon, nutrient and phosphorus cycling in the landscape, including plant growth, soil mineralization, denitrification and carbon and phosphorus flushes when streams flow again, for which microorganisms lysis is the main hypothesis. In the approaches used, particularly in modeling, bio-geochemical processes were mainly represented by empirical functions. There was no explicit representation of the micro-organisms dynamics and their functions. Thus scientists examined the capacity of soils to store carbon or emit $\mathrm{CO}_{2}$, by analyzing microbial community diversity along gradients of soil moisture and soil organic matter. The effect of agricultural practices on soil microbial communities was also studied. The microbial communities were determined by their biomass and bioper DNA analysis in all the soils of the catchment. Understanding ecological functions of microorganisms is crucial for assessing the effect of climate change on water quality, since microorganisms and plants strongly react to temperature and moisture.

Approach: reinforcement of ecological observations in the catchment

Microbial biomass, diversity and enzymatic activities were included in the 2013 soil survey. Streams were surveyed to define their ecological quality. Distribution of water temperature in the catchment was studied to identify locations where groundwater flow enters the stream and locations that could serve as habitats for certain aquatic organisms. All these observations and their analysis have not yet been published.

\section{How have the scientific structures changed during this $\mathbf{5 0}$ years period?}

Agro-environmental studies started in 1971 (Fig. 4). The first steps were performed by scientists from Irstea (for 'Institut National de Recherche en Sciences et Technologies pour l'Environnement et l'Agriculture', called Cemagref at that time), a small French research institute. Twenty years later, the INRA (for 'Institut National de la Recherche Agronomique') started to consider catchments as a new research approach, following the trend of the international scientific community of using experimental catchments to study hydrological and hydrochemical processes. In the 2000's, the CNRS (for 
'Centre National de la Recherche Scientifique') joined the research team, bringing biogeochemistry and placing interactions among water and chemical elements, groundwater fluctuations and biogeochemical transformation at the heart of the studies.

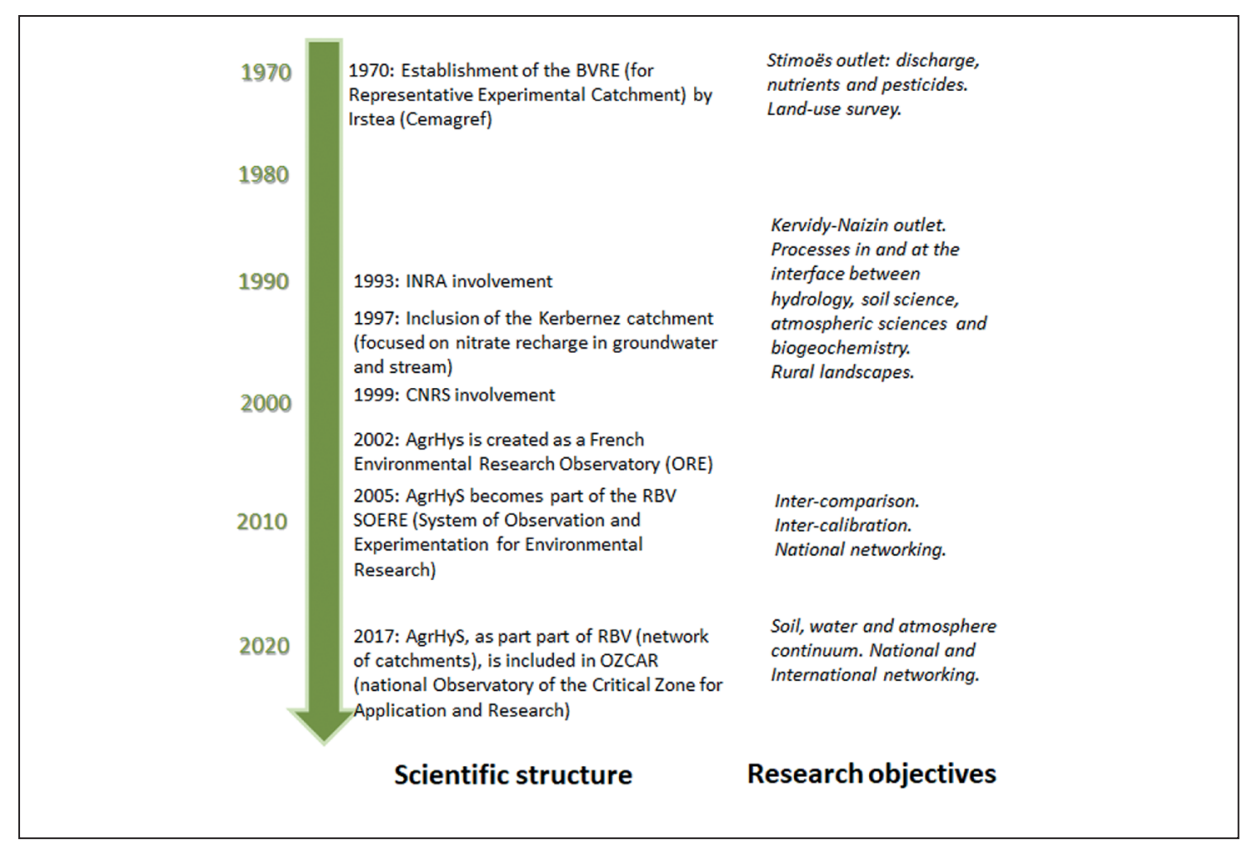

Figure 4. Historical retrospective of the scientific structures that have governed the KervidyNaizin catchment and the main research objectives.

The existence of the observatory and the strong collaborations between INRA and CNRS encouraged the creation of CAREN (for 'Centre Armoricain de Recherche en ENvironnement', today called OSUR for 'Observatoire des Sciences de l'Univers de Rennes'), a federative research institute for environmental scientists working in Rennes, the capital of Brittany, which also includes teaching activities. The scientific community grew as observations broadened, strengthening this federative research institute. The Kervidy-Naizin catchment is now a site for interdisciplinary research in environment that mobilizes a large research community of approximately 30 scientists and technicians locally, who all have national and international collaborations. It was also in the 2000's when the French Ministry of Education and Research (FMER) decided to award with the ORE (for "Observatory of Research in the Environment") label highly equipped catchments in order to highlight the need for long-term observations (and thus longterm funding) that help solving scientific questions on environmental issues, such as the response time of catchments to human activities and the impacts of global change. This label has two requirements: 1) long-term analysis of a common set of variables, a kind of basic basket for the observatory, which are archived in a common database and 2) data availability for the entire scientific community. Since the 2000 s, the KervidyNaizin catchment, together with the Kerbernez catchments, constitutes the AgrHys ORE, 
one of the 15 sites labeled as an ORE by the FMER, and receives permanent funding for long-term observations. The Kervidy-Naizin catchment is also frequently used to teach students and train agricultural advisors and water managers. The CRESEB (for 'Center for Resources and Scientific Expertise on Water in Brittany'), which acts as an interface between science and society in Brittany, is particularly interested in using the Kervidy-Naizin catchment as a platform and reference for discussing water quality issues and analyzing the transfer of results and monitoring equipment and strategies to other catchments. However, the Kervidy-Naizin catchment does not have the "French National Observation Service" label, which provides a site with permanent human resources. National labels, whatever they are, are the "Holy Grail", i.e. a never achieved objective for the team in charge of the observatory, since these often renewed labels ensure permanent observations and provide permanence to the observatory itself.

Five years after the first labelling initiative, the FMER created the "System of Observation and Experimentation for Environmental Research" (SOERE) label to maintain long-term observatories in multiple research fields, including catchment science, for which the SOERE was named RBV (for "Réseau des Bassins Versants"). The SOERE RBV consists of a network of approximately 20 catchments distributed throughout France and overseas (India, Africa and South America) and aims at federating the scientific community working in catchments by promoting a variety of activities: e.g., inter-calibration, inter-comparisons along gradients, annual scientific meetings, a common web portal, etc. SOERE RBV is now included with other SOERE in OZCAR (National Observatory of the Critical Zone for Application and Research). The ORE AgrHyS is one of their master sites. Establishing multiple sites of different SOERE in the same region would increase the wealth and length of the data series acquired from different topics over time. This important labeling and structuring effort, highly time consuming, has been developed in other countries (such as TERENO in Germany, DTC in the United Kingdom or LTAR in the US), and constitutes the current effort of the scientific community and research administration in organizing long-term observation sites in Europe and worldwide (CZO, E-LTER, etc.).

\section{Current challenges and perspectives}

\subsection{Knowledge integration}

Current efforts still focus on the integration of processes across the landscape, such as nitrogen and phosphorus cycles in wetlands, carbon in soil water and soil gaseous emissions. The knowledge gained from the Kervidy-Naizin catchment has been enriched over the decades by the existence of long-term data series and by keeping the sampling equipment always at the same locations. It is of paramount importance to maintain the memory of studies and results over multiple generations of scientists and the publication of books has been a good way to achieve this. The long time-series of data has enabled recent retrospective analyses, particularly on the influence of climate on intra- and interannual variations in water quality, an extremely relevant topic because of uncertainties in climate projections (Aubert et al., 2013). 
The deep knowledge gained in this small catchment on a broad range of topics has enabled the current development of a more integrative approach. This is evident in studies dealing with the coupling/decoupling of biogeochemical cycles, the common and/or distinct nutrient production areas, or the synchronization and desynchronization of export between carbon, azote and phosphorus. These studies can contribute to assess changes in ratios of multiple chemical elements in time, from flood events to long time series, and in space, from field to catchment scales. Other recent studies focus on the functions and services provided by soils in rural landscapes such as agricultural production, water and air regulation or climatechange mitigation. Again, this is possible thanks to the vast amount of information coming from field data and simulated data in this small area.

\subsection{Transposition and extrapolation of the results}

Scientists studying Kervidy-Naizin wish to look beyond the small catchment scale, particularly at larger catchments whose water is managed. They want to determine whether the hypotheses and models built for the Kervidy-Naizin catchment are of generic value and could be used to design mitigation strategies over larger areas. How is the diversity in terms of water quality signature in headwater systems? What factors tend to control water and nutrient export? How do processes and controlling factors interact at a larger (regional) scale? An additional topic that needs to be addressed is the propagation of water quality signatures from headwater catchments to mesoscale catchments $\left(100-100,000 \mathrm{~km}^{2}\right)$, since the mesoscale aggregates a variety of headwater situations. For this purposes, increasing attention is being paid to the Blavet catchment $\left(2000 \mathrm{~km}^{2}\right)$, which contains the small Kervidy-Naizin catchment, and to the analysis of the diversity of its landscape features such as topography, soil composition and structure, land use and agricultural systems. The key issue behind moving to this larger scale is to know whether proxies can be defined to extrapolate local knowledge on nutrient export to a variety of larger and more operational catchments.

\subsection{Innovation: technology and open science}

Research in small catchments is strongly linked to the development of new equipment. Developing and installing new equipment and/or new monitoring strategies is a central goal of the research group. For example, high-frequency chromatography equipment has been recently installed to analyze water quality (all anions and cations) every 20 minutes, while an optic fiber will be installed in the stream to measure the temperature along the stream. New technologies for high resolution assessment of soil and water quality in response to agricultural and hydroclimatic changes can be installed and tested in Kervidy-Naizin, since they can be easily calibrated with and compare to the large amount of equipment and information existing in the catchment.

In the short term it is likely more innovative and strategic to consider this highly equipped catchment as an interface between science and society by developing innovative ways of sharing data and know-how. For example, the GeoSAS web service has been developed to allow the user to navigate over the catchment, view its equipment and consult observed data and metadata. Such a tool could be developed for observed but also simulated data by models in order to explore the current and the future situations of the catchment. 


\subsection{Internationalization}

Although international collaboration has increased in the last years (including catchment inter-comparison, methodological developments, etc.), internationalisation remains relatively limited in Kervidy-Naizin. A challenge for this environmental observatory, as for all environmental observatories, is to take part in European and international networks that favor the collaboration between scientists from many countries as done e.g. in the recent work by Mellander et al., (2018). This is currently possible because of the exceptionally long and rich data series available in the KervidyNaizin catchment. The recent development of European and other international networks suggests that this goal can be a reality in the near future.

\section{Conclusion}

The Kervidy-Naizin catchment is currently much more than a hydrological observatory. It is an instrument for developing new knowledge in environmental sciences, from catchment hydrology to other disciplines dealing with soil, the atmosphere and the ecosystems, and involved in the functioning of the "critical zone" (i.e. the fragile interface at the surface of the earth). The scientific world makes scientific questions to evolve, of course, but so does societal demand. For example, questions about soil functions and services have recently emerged from society, to fight against urbanization processes. How can we evaluate soil functions such as biomass production, water and air regulation, or biodiversity? A very well monitored catchment such as Kervidy Naizin constitutes a unique site to develop methodologies to respond to that societal demand. Consequently, we see few differences between LTER sites (theoretically more focused on socio-ecological issues) and CZO sites (theoretically more focused on hydrogeochemical issues) as their philosophies progressively move closer to each another, as demonstrated by the 50 years of monitoring and research development in the KervidyNaizin catchment.

\section{Acknowledgements}

We deeply thank all the staff involved in the ORE AgrHys, particularly in the Kervidy-Naizin catchment. We cannot cite all of them, at the risk of forgetting somebody, but we emphasize the key role of the AgrHys's management committee, the physical and chemical engineers, and the computer science staff because without them nothing could have been done. We thank the reviewers of this article for their relevant comments.

\section{References}

Akkal, N. 2010. Description des systèmes d'exploitation du bassin versant de Kervidy-Naizin. NitroEurope IP, $71 \mathrm{pp}$.

Ambroise, B. 1999. Du BVRE, bassin versant de recherche expérimental, au BVR, bassin versant de recherche. In: D. Houi, J.L. Verrel (Eds.), Du concept de BVRE à celui de zone atelier dans les recherches menées en eaux continentales, Cemagref Edition, pp. 11-24. 
Anderson, S.P., Bales, R.C., Duffy, C.J. 2008. Critical Zone Observatories: Building a network to advance interdisciplinary study of Earth surface processes. Mineralogical Magazine 72 (1), 7-10. https://doi.org/10.1180/minmag.2008.072.1.7.

Aubert, A.H., Gascuel-Odoux, C., Gruau, G., Akkal, N., Faucheux, M., Fauvel, Y., Grimaldi, C., Hamon, Y., Jaffrezic, A., Lecoz-Boutnik, M., Molenat, J., Petitjean, P., Ruiz, L., Merot, P. 2013. Solute transport dynamics in small, shallow groundwater-dominated agricultural catchments: insights from a high-frequency, multisolute $10 \mathrm{yr}$-long monitoring study. Hydrology and Earth System Sciences 17 (4), 1379-1391. https://doi.org/10.5194/hess-171379-2013.

Aubert, A.H., Kirchner, J.W., Gascuel-Odoux, C., Faucheux, M., Gruau, G., Merot, P. 2014. Fractal water quality fluctuations spanning the periodic table in an intensively farmed watershed. Environmental Science \& Technology 48 (2), 930-937. https://doi.org/10.1021/es403723r.

Beaujouan., V., Durand, P., Ruiz, L., Aurousseau, P., Cotteret, G. 2002. A hydrological model dedicated to topography-based simulation of nitrogen transfer and transformation: rationale and application to the geomorphology-denitrification relationship. Hydrological Processes 16 (2), 493-507. https://doi.org/10.1002/hyp.327.

Bell, M., Flechard, C., Fauvel, Y., Häni, C., Sintermann, J., Jocher, M., Menzi, H., Hensen, A., Neftel, A. 2017. Ammonia emissions from a grazed field estimated by miniDOAS measurements and inverse dispersion modelling. Atmospheric measurement techniques 10 , 1875-1892. https://doi.org/10.5194/amt-10-1875-2017.

Benhamou, C., Salmon-Monviola, J., Durand, P., Grimaldi, C., Merot, P. 2013. Modeling the interaction between fields and a surrounding hedgerow network and its impact on water and nitrogen flows of a small watershed. Agricultural Water Management 121, 62-72. https://doi. org/10.1016/j.agwat.2013.01.004.

Beven,K.,Kirkby,M.J.1979. A physicallybased variable contributing area model of basin hydrology. Hydrological Sciences Bulletin 24, 43-69. https://doi.org/10.1080/02626667909491834.

Bullock, A., Acreman, M. 2003. The role of wetlands in the hydrological cycle. Hydrology and Earth System Sciences 7 (3), 358-389. https://doi.org/10.5194/hess-7-358-2003.

Buysse, P., Flechard, C.R., Hamon, Y., Viaud, V. 2016. Impacts of water regime and land-use on soil $\mathrm{CO}_{2}$ efflux in a small temperate agricultural catchment. Biogeochemistry 130, 267-288. https://doi.org/10.1007/s10533-016-0256-y.

Callahan, J.T. 1984. Long-Term Ecological Research. BioScience 34 (6), 363-367. https://doi. org/10.2307/1309727.

Cann, Ch. 1998a. Evolution de l'agriculture et de sa pression polluante sur le bassin et en Bretagne. In: C. Cheverry (Ed.), Agriculture intensive et qualité des eaux, Inra Editions, pp. 25-40.

Cann, Ch. 1998b. Transferts de polluants vers l'eau. In: C. Cheverry (Ed.), Agriculture intensive et qualité des eaux, Inra Editions, pp. 233-250.

Chaplot, V., Walter, C., Curmi, P. 2000. Improving soil hydromorphy prediction according to DEM resolution and available pedological data. Geoderma 97 (3-4), 405-422. https://doi. org/10.1016/S0016-7061(00)00048-3.

Chaplot, V., Bernoux, M., Walter, C., Curmi, P., Herpin, U. 2001. Soil carbon storage prediction in temperate hydromorphic soils using a morphologic index and digital elevation model. Soil Science 166 (1), 48-60. https://doi.org/10.1097/00010694-200101000-00008.

Cheverry, C. 1998. Agriculture intensive et qualité des eaux. Inra Editions, 297 pp.

Crave, A., Gascuel-Odoux, C. 1997. The influence of topography on time and space distribution of soil surface water content. Hydrological Processes 11 (2), 203-210. https://doi.org/10.1002/ (SICI)1099-1085(199702)11:2<203::AID-HYP432>3.0.CO;2-K. 
Curmi,P.,Durand,P., Gascuel-Odoux,C.,Merot,P., Walter,C., Taha, J.M. 1998. Hydromorphic soils, hydrology and water quality: spatial distribution and functional modelling at different scales. Nutrient Cycling in Agroecosystems 50, 127-142. https://doi.org/10.1023/A:1009775825427.

Davranche, M., Pourret, O., Gruau, G., Dia, A., Le Coz-Bouhnik, M. 2005. Adsorption of REE(III)humate complexes onto $\mathrm{MnO}_{2}$ : Experimental evidence for cerium anomaly and lanthanide tetrad effect suppression. Geochimica et Cosmochimica Acta 69 (20), 4825-4835. https://doi. org/10.1016/j.gca.2005.06.005.

Davranche, M., Grybos, M., Gruau, G., Pedrot, M., Dia, A., Marsac, R. 2011 . Rare earth element patterns: A tool for identifying trace metal sources during wetland soil reduction. Chemical Geology 284 (1-2), 127-137. https://doi.org/10.1016/j.chemgeo.2011.02.014.

Dia, A., Gruau, G., Olivie-Lauquet, G., Riou, C., Molenat, J., Curmi, P. 2000. The distribution of rare earth elements in groundwaters: assessing the role of source-rock composition, redox changes and colloidal particles. Geochimica et Cosmochimica Acta 64 (24), 4131-4151. https://doi.org/10.1016/S0016-7037(00)00494-4.

Dupas, R., Gascuel-Odoux, C., Gilliet, N., Grimaldi, C., Gruau, G. 2015a. Distinct export dynamics for dissolved and particulate phosphorus reveal independent transport mechanisms in an arable headwater catchment. Hydrological Processes 29 (14), 3162-3178. https://doi. org/10.1002/hyp.10432.

Dupas, R., Gruau, G., Gu, S., Humbert, G., Jaffrezic, A., Gascuel-Odoux, C. 2015b. Groundwater control of biogeochemical processes causing phosphorus release from riparian wetlands. Water Research 84, 307-314. https://doi.org/10.1016/j.watres.2015.07.048.

Durand, P., Torres, J.L.J. 1996. Solute transfer in agricultural catchments: The interest and limits of mixing models. Journal of Hydrology 181 (1-4), 1-22. https://doi.org/10.1016/00221694(95)02922-2.

Durand, P., Moreau, P., Salmon-Monviola, J., Ruiz, L., Vertes, F., Gascuel-Odoux, C. 2015. Modelling the interplay between nitrogen cycling processes and mitigation options in farming catchments. Journal of Agricultural Science 153, 959-974. https://doi.org/10.1017/ S0021859615000258.

Fovet, O., Ruiz, L., Faucheux, M., Molenat, J., Sekhar, M., Vertes, F., Aquilina, L., Gascuel-Odoux, C., Durand, P. 2015. Using long time series of agricultural-derived nitrates for estimating catchment transit times. Journal of Hydrology 522, 603-617. https://doi.org/10.1016/j. jhydrol.2015.01.030.

Fovet, O., Humbert, G., Dupas, R., Gascuel-Odoux, C., Gruau, G., Jaffrezic, A., Thelusma, G., Faucheux, M., Gilliet, N., Hamon, Y., Grimaldi, C. 2018. Seasonal variability of stream water quality response to storm events captured using high-frequency and multi-parameter data. Journal of Hydrology 559, 282-293. https://doi.org/10.1016/j.jhydrol.2018.02.040.

Franks, S.W., Gineste, P., Beven, K.J., Merot, P. 1998. On constraining the predictions of a distributed model: The incorporation of fuzzy estimates of saturated areas into the calibration process. Water Resources Research 34 (4), 787-797. https//doi.org/10.1029/97WR03041.

Grybos, M., Davranche, M., Gruau, G., Petitjean, P. 2007. Is trace metal release in wetland soils controlled by organic matter mobility or Fe-oxyhydroxides reduction? Journal of Colloid and Interface Science 314 (2), 490-501. https//doi.org/10.1016/j.jcis.2007.04.062.

Gu, S., Gruau, G., Dupas, R., Rumpel, C., Creme, A., Fovet, O., Gascuel-Odoux, C., Jeanneau, L., Humbert, G., Petitjean, P. 2017. Release of dissolved phosphorus from riparian wetlands: Evidence for complex interactions among hydroclimate variability, topography and soil properties. Science of the Total Environment 598, 421-431. https://doi.org/10.1016/j. scitotenv.2017.04.028.

Humbert, G., Jaffrezic, A., Fovet, O., Gruau, G., Durand, P. 2015. Dry-season length and runoff control annual variability in stream DOC dynamics in a small, shallow groundwater- 
dominated agricultural watershed. Water Resources Research 51, 7860-7877. https//doi. org/10.1002/2015WR017336.

Lambert, T., Pierson-Wickmann, A.C., Gruau, G., Thibault, J.N., Jaffrezic, A. 2011. Carbon isotopes as tracers of dissolved organic carbon sources and water pathways in headwater catchments. Journal of Hydrology 402 (3-4), 228-238. https://doi.org/10.1016/j.jhydrol.2011.03.014.

Le Bissonnais, Y., Cros-Cayot S., Gascuel-Odoux, C. 2002. Topographic dependence of aggregate stability, overland flow and sediment transport. Agronomie 22, 489-501. https//doi. org/10.1051/agro:2002024.

Mellander, P.E., Jordan, P., Bechmann, M., Fovet, O., Shore, M.M., McDonald, N.T., GascuelOdoux, C. 2018. Integrated climate-chemical indicators of diffuse pollution from land to water. Scientific Reports 8 (944). http://doi.org/10.1038/s41598-018-19143-1.

Merceron, M. 1999. Pollutions diffuses: du basin versant au littoral. Ifremer Editions, $\mathrm{N}^{\circ} 24,350 \mathrm{pp}$.

Merot, P., Crave, A., Gascuel-Odoux, C., Louhala, S. 1994. Effect of saturated areas on backscattering coefficient of the ERS-1 synthetic-aperture radar - first results. Water Resources Research 30 (2), 175-179. https//doi.org/10.1029/93WR02920.

Merot, P., Ezzahar, B., Walter, C., Aurousseau, P. 1995. Mapping waterlogging of soils using digital terrain models. Hydrological Processes 9 (1), 27-34. https//doi.org/10.1002/hyp.3360090104.

Merot, P., Hubert-Moy, L., Gascuel-Odoux, C., Clement, B., Durand, P., Baudry, J., Thenail, C. 2006. A method for improving the management of controversial wetland. Environmental Management 37 (2), 258-270. https://doi.org/10.1007/s00267-004-0391-4.

Molenat, J., Gascuel-Odoux, C. 2002. Modelling flow and nitrate transport in groundwater for the prediction of water travel times and of consequences of land use evolution on water quality. Hydrological Processes 16 (2), 479-492. https//doi.org/10.1002/hyp.328.

Molenat, J., Davy, P., Gascuel-Odoux, C., Durand, P. 1999. Study of three subsurface hydrologic systems based on spectral and cross-spectral analysis of time series. Journal of Hydrology 222 (1-4), 152-164. https://doi.org/10.1016/S0022-1694(99)00107-9.

Molenat, J., Gascuel-Odoux, C., Davy, P., Durand, P. 2005. How to model shallow water-table depth variations: the case of the Kervidy-Naizin catchment, France. Hydrological Processes 19 (4), 901-920. https//doi.org/10.1002/hyp.5546.

Molenat, J., Gascuel-Odoux, C., Ruiz, L., Gruau, G. 2008. Role of water table dynamics on stream nitrate export and concentration in agricultural headwater catchment (France). Journal of Hydrology 348 (3-4), 363-378. https://doi.org/10.1016/j.jhydrol.2007.10.005.

Molenat, J., Gascuel-Odoux, C., Aquilina, L., Ruiz, L. 2013. Use of gaseous tracers (CFCs and $\mathrm{SF}_{6}$ ) and transit-time distribution spectrum to validate a shallow groundwater transport model. Journal of Hydrology 480, 1-9. https://doi.org/10.1016/j.jhydrol.2012.11.043.

Morel, B., Durand, P., Jaffrezic, A., Gruau, G., Molenat, J. 2009. Sources of dissolved organic carbon during stormflow in a headwater agricultural catchment. Hydrological Processes 23 (20), 2888-2901. https//doi.org/10.1002/hyp.7379.

Pourret, O., Davranche, M., Gruau, G., Dia, A. 2007. Organic complexation of rare earth elements in natural waters: Evaluating model calculations from ultrafiltration data. Biogeochemica Acta 71, 2718-2735. https://doi.org/10.1016/j.gca.2007.04.001.

Tete, E., Viaud, V., Walter, C. 2015. Organic carbon and nitrogen mineralization in a poorly-drained mineral soil under transient waterlogged conditions: an incubation experiment. European Journal of Soil Science 66 (3), 427-437.

Viaud, V., Durand,P., Merot,P., Sauboua, E., Saadi,Z. 2005. Modeling the impact of the spatial structure of a hedge network on the hydrology of a small catchment in a temperate climate. Agricultural Water Management 74 (2), 135-163. https://doi.org/10.1016/j.agwat.2004.11.010.

Walbridge, M.R. 2013. A Long-Term Agro-ecosystem Research (LTAR) Network of the United States. Orgeval Basin, Paper No. 58, 51 pp. 